\title{
“刚性・弹性・韧性” 深圳市创新型产业的空间规划演进与思考
}

"Rigidity · Flexibility · Resilience": The Thought and Evolution of Spatial Planning on Innovative Industries in Shenzhen

摘要：塑造创新空间是提升区域竞争力的重要战略，但是如何通过规划手 段来实施是具有区域差异的议题。与西方规划对物质空间的弱干预不同, 中国的规划对物质空间一直有强干预的传统。但在城市化、全球化背景下， 中国的规划技术正由刚性走向韧性，面向创新的产业空间布局规划也面临 转型。深圳是中国的创新极区与规划先锋, 本文通过探讨其创新型产业空 间布局规划的演变, 厘清韧性规划中刚性、弹性的具体表现形式及耦合机制, 系统性建构由结构韧性、控制韧性与过程韧性共同构成的韧性规划理论框 架, 为未来进一步探索中国产业转型与规划空间干预机制转型背后的逻辑 奠定基础。

Abstract: Improving the space arrangement of innovative industry is an important issue and regional characteristics must be taken into account during the making of urban planning. Differ from western planning which has a weak intervention on physical space, Chinese planning always tends to use strong intervention on physical space arrangement. However, Chinese planning technique has been changing from rigid to resilient. The spatial planning of innovative industry is also transforming due to the challenges. Shenzhen is the innovative polar and planning pioneer in China. This research discusses the evolution of the spatial layout planning of innovation industry in Shenzhen, clarifies specific forms and coupling mechanism of rigidity and flexibility in resilient control, establishes a resilient planning theory framework that is composed of structure resilience, control resilience and process resilience, aiming to further explore the logic behind industry transformation and the mechanism of planning intervention.

关键词: 刚性; 弹性; 韧性; 创新型产业; 空间规划演进

Keywords: Rigidity; Flexibility; Resilience; Innovative Industry; Evolution of Spatial Planning

国家自然科学基金青年科学基金项目（41401122）“深圳电子信息产业创新 系统的空间组织特征和演化机制”

作者: 张惠璇, 北京大学城市规划与设计学院城市与区域规划专业, 硕士研究生。 1030051804@qq.com

刘青 (通信作者), 北京大学城市规划与设计学院城市与区域规划专业, 助理研究员。liuq@pkusz.edu.cn

李贵才, 北京大学城市规划与设计学院城市与区域规划专业, 教授、博 士生导师。ligc@pkusz.edu.cn
引言

与西方规划对物质空间的弱干预不同，中国的规划 从计划经济以来对物质空间一直有强干预的传统。但在 城市化、全球化和经济进一步开放的过程中, 市场剧烈 转型, 空间快速重构, 传统的自上而下的指令性空间安 排已难以应对灵活多变的社会经济环境, 中国规划技术 亟待由刚性向弹性再到韧性的转变以充分支撑不断扩张 的城市空间发展需求, 提高城市对不确定扰动的适应调 整能力 ${ }^{[1]}$ 。早在 1960 年代就有学者提出 “簇群城市”[2] “有 机疏散” ${ }^{[3]}$ 、“插人式城市”、“渐进式发展” ${ }^{[1 \mid 36}$ 、“网格 城市” 55136 等城市概念模型, 将弹性思维逐渐纳人城市规 划理念, 到 1990 年代, 国内外学者基于弹性规划理论与 城市实践对规划技术进行提炼, 形成了“多目标决策” ${ }^{[6]}$ 、 “弹性发展单元” ${ }^{[7] 66}$ 、“白色地段” ${ }^{[8]}$ 、“混合用地” ${ }^{19]}$ 、“区 间控制”、“动态组织” ${ }^{[440}$ 等规划技术体系。但一些学者 认为过度强调弹性而弱化刚性的规划会诱发市场逐利行 为、削弱规划的执行力 ${ }^{[10,11]}$, 弹性规划并非是无限制的 弹性 ${ }^{[5] 35}$, 应探索建立刚性与弹性的耦合机制, 既强化规 划管控手段与确定性要素的刚性, 又充分保障城市空间 对现实环境变化的适应力, 促进规划向韧性控制转变 ${ }^{14139}$ 。 因此, 进一步研究厘清㓞性规划中刚性和弹性的具体表 现形式以及建立两者的技术关联十分必要。

在全球化、信息化与区域一体化背景下，促进依赖 于创新性活动与高新技术应用的创新型产业发展成为各 国提升竞争力的重要战略。由于创新型产业巨大的投资 风险和研发投人的外部性, 政府对创新产业培育发展 的空间干预和规划管制显得尤为重要 ${ }^{[12]}$ 。然而, 随着 产业功能和空间特性的快速变化, 面向创新的产业空间 布局规划正面临由刚性到弹性再到韧性的转型。现有关 
于创新产业布局的研究主要集中于对高新技术产业的空间 选择 ${ }^{[13,14]}$ 、布局模式 ${ }^{[15,16]}$ 、演化形式及形成机制 ${ }^{[17,18]}$ 的探 讨, 强调政府在产业升级、规划布局及园区软环境塑造 ${ }^{[19]}$ 方面的作用, 研究尺度由单个园区转向城市层面乃至国家层 面 ${ }^{[20,21]}$, 也不断纳人大学科技园、边缘城市、专业镇、高技 术产业带、企业分葟等日益丰富的布局形式及内涵, 但缺 少应对产业战略调整与布局演变的空间规划探讨。对应不 同产业发展阶段具体采取何种规划实现形式, 还需进行实 证研究。

深圳作为中国十大创新城市之首、首个国家创新型城市 及首批国家综合改革配套试验区, 拥有强劲的创新优势及创 新能力。深圳也被认为是完全依照规划建设起来的城市 ${ }^{[22]}$, 其城市规划实践对市场经济环境具有很强的适应能力 ${ }^{[23] 60}$, 创新产业规划也是如此。在 30 多年间, 深圳的产业战略从 发展高新技术产业、塑造创新产业集群到构建区域创新体系, 空间布局经历了 “产业园区一产业带一功能网络” 由点及面 的演化, 规划思维也一直配合着产业发展路径不断调整, 从 刚性、弹性规划逐渐转向韧性规划。基于此, 本文以深圳为例, 梳理深圳创新型产业布局的演变历程与空间规划特征, 系统 性建构㓞性规划理论框架, 以深层次揭示政府在不同时期为 促进创新而编制的各类产业规划内涵, 探析中国规划转型的 细节特征, 为塑造韧性创新空间、推进区域创新体系构建提 供决策参考。

\section{1 概念解析}

\section{1 刚性与刚性规划}

刚性是指事物在外力作用下不易发生形变、难以通融和 改变的性质 ${ }^{224]}$ 。刚性规划是指规划在战略思想、指标结构、 编制程序、管制规则等方面所具有的权威性、固定性和指令 性 ${ }^{[23] 60-62}$ 。城市规划中的刚性体现在秉持以人为本、绿色低碳、 历史传承、协调发展的规划理念 ${ }^{[25]}$, 对道路、绿地、河道等 城市 “五线” 实施空间开发管控 ${ }^{[26]}$, 严格划定土地用途分 区及其用途管制规则 ${ }^{[27]}$, 逐级落实城市建设指令性、约束性 指标, 强化控规编制实施的执行力和规范化等方面 ${ }^{[25 !}$ 。产业 规划中的刚性要素主要包括不同类型产业布局的空间选择偏 好, “点、轴带、功能区” 等模块化的产业空间语言 ${ }^{[28]}$, 产 业与土地、人口、基础设施的协调统一关系, 产业准人标准 的严格约束以及产业园区内工业用地规划管理的强化等 ${ }^{[29]}$ 。

\section{2 弹性与弹性规划}

弹性的概念源于物理学, 本意是指当物体所受的外力在 弹性限度内, 外力撤销后能恢复原来大小和形状的性质 ${ }^{[30]}$ 。 随后这一概念逐渐被引人到生态学、社会一生态系统、社会一
经济系统等研究领域中, 其内涵也得以丰富和延伸 ${ }^{[1,32]}$ 。但 本质上都具有以下特性：（1）在承受或吸收一定外界干扰的 情况下能够维持基本结构和功能特征不变;（2）能够建立自 组织、自适应、自我恢复的能力 ${ }^{[33]}$ 。近年来, 弹性被逐渐应 用于城市规划领域, 表征城市对社会经济发展的不确定性和 复杂性的适应能力 ${ }^{[34]}$, 并出现了 “弹性城市”、“城市生态弹 性”、“城市工程弹性”、“城市经济社会弹性”等新理念 ${ }^{[35]}$ 。

弹性规划是为了提升城市规划与城市空间应对不确定社 会经济发展变化的能力所采取的一种规划技术手段 ${ }^{[7] 64}$ 。城 市规划中的弹性主要体现在构建有伸缩余地的城市空间结 构, 扩大有限规划指标的可浮动范围, 实行频繁、滚动式规 划修编方式, 引人市场机制激励开发建设行为, 促进自上而 下与自下而上规划体系的双向互动等方面 ${ }^{[36]}$ 。目前应用于产 业布局规划中的弹性手段主要包括预留 “灰色用地”、“白色 地段” 以赋予地块易置换的用地功能 ${ }^{[37]}$, 拓展 “ $2+X ”$ 协调 的远景用地空间 ${ }^{[38]}$, 构筑弹性的园区道路系统 ${ }^{[39]}$ 等。

\section{3 韧性与韧性规划}

㓞性是物体受外力作用时产生变形但不折断的性质, 兼 具刚性力与弹性力。韧性与弹性的概念有一定相似性, 但实 质却存在差异。弹性强调物体在弹性极限内可产生变化并恢 复原状的性质, 基本可以认为不具有刚性, 且当外力超过弹 性极限时物体会发生断裂。而韧性则是刚性和弹性的耦合, 既能够保证自身在结构或功能方面的稳定性, 又能够以适当 的手段吸收和缓冲外界变化产生一定形变, 且当受到较大或 突然性的外力作用时, 韧性物体比弹性物体呈现出更好的稳 定性和长期适应能力 (图 1)。

㓞性规划是以韧性思维导控城市物质空间、城市建设行 动与城市发展过程 ${ }^{[4] 36-38}$ 。城市规划中的韧性主要体现在利用 道路系统、生态绿地等刚性核心要素建构弹性空间, 运用容 积率奖励、二维和三维土地复合利用等弹性手段运作刚性指 标体系, 建立 “滚动规划” 刚性管理制度等。由此可见, 韧 性规划并不是刚性与弹性的简单相加, 而是通过建立内在技 术关联实现两类规划工具的巧妙耦合。由韧性规划营建的产 业空间应既具有稳定的发展骨架, 又留有可变通的弹性区间, 能够在接收和消化外界环境变化的同时, 通过各组成部分间 的优化、协调和重组维持基础结构和功能运作, 并获得自身 长期适应能力的提升 ${ }^{[40]}$ 。

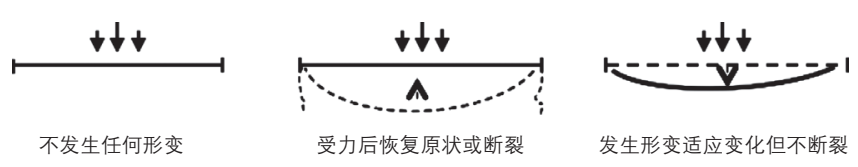

图 1 刚性、弹性、韧性内涵解析示意图 资料来源：作者绘制 


\section{2 深圳市创新型产业规划的演进}

通过对深圳市 1991-2013 年高新技术产品产值的分析, 结合深圳创新政策与产业规划历程, 可将深圳的创新产业发 展分为三个阶段：1995-2000 年萌芽初创期、2001-2005 年快速成长期、2006 年至今成熟稳定期（图 2)。对应于不 同产业发展阶段, 规划思维与技术也表现出较为明显的阶段 性特征, 经历了由刚性到弹性再到韧性规划的转变。

\section{1 产业园区（1995一2000 年）: 刚性规划阶段}

\subsection{1 规划背景}

深圳建立之初, 以“三来一补”企业为主导, 形成了劳 动密集型工业结构。为适应需求结构的迅速变化, 促进工业 经济的高效发展, 深圳积极进行产业结构的优化调整。1995 年, 深圳市政府下发《关于推动科学技术进步的决定》, 确 立 “以高新技术产业为先导, 先进工业为基础” 的产业定位, 提出科学规划高新技术产业布局, 加速发展高新技术产业开 发区。初步建立起良好的高新技术产业发展环境。

\subsection{2 园区规划中的刚性思维}

这一时期的深圳创新产业正处于萌芽起步阶段, 产业规 划仍带有较强的指令性和干预性。政府层面通过直接编制产 业园区规划自上而下塑造专业化产业聚集区, 其跳跃了以大 学和研究机构为起点的园区的企业自发集中阶段, 利用规划 手段促成企业和研究机构在园区内集中。1996 年 9 月, 深 圳市委、市政府选择在当时并不是市中心的南山区但交通区 位良好且靠近深圳大学等科研资源的地块设立深圳高新技术 产业园区, 整合深圳科技工业园、中国科技开发院、高新技 术工业村等几个小区, 实行 “一区多园” 式管理。为推动园 区分类发展, 高新产业园领导小组组织编制了《深圳市高新 技术产业园区发展规划 (1997-2000)》, 对高新区实行统一 规划和 “模块化” 布局, 形成南区以技术开发型企业为主, 中区发展生物工程、新材料产业, 北区安置大型生产型高新 技术企业及生活居住的地域功能布局。

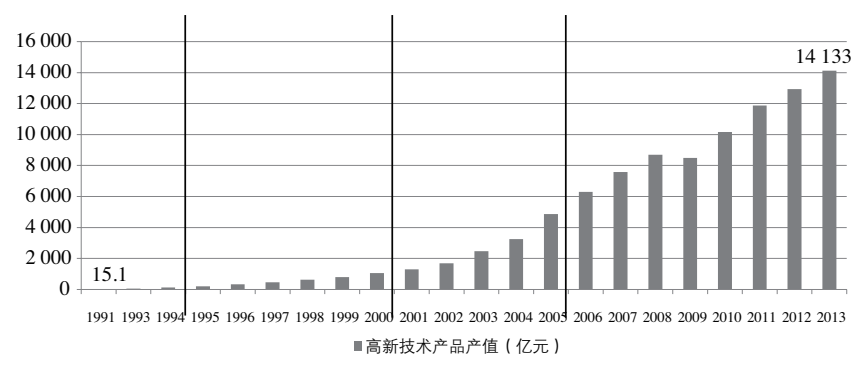

图 2 1991一2013 年深圳市高新技术产品产值分布图 资料来源：1991-2013 年深圳市国民经济和社会发展统计公报
产业园区阶段的规划实质上是一种静态蓝图式规划, 其 刚性效力主要体现在以下几个方面。

（1）用地布局方面, 市高新办会同市规划国土局等部门 成立高新区用地规划实施协调小组, 对用地性质、规模、比 例等指标实施严格管控, 清理整顿不符合高新技术产业发展 要求的已建或已划红线用地, 为北、中、南区工业用地划定 标准地块 (企业的单独占地面积不得小于 $2 \mathrm{hm}^{2}$ ), 为小型工 业企业提供标准厂房, 虽保证了规划用地的完整性, 但却缺 乏适应未来产业升级改造需求的弹性。产业园区内部以功能 区为空间语言对核心要素进行组织布局, 形成了研发区、工 业区、生活配套区等严格的功能分区（图 3), 但不同功能区 之间融合关联度较低, 存在明显的功能区隔。除此之外, 这 一时期的用地规划虽通过住宅区与临近工业区的成组配置强 化生产、生活互动发展的思维, 但仍沿袭了以产业为核心配 置要素的刚性传统逻辑, 人口、土地、基础设施配套未形成 协同发展的良性机制, 园区以集中成片的工业用地为主, 缺 乏从科研、生产到公共配套设施的一体化建设, 居住供给与 需求相抵, 约有 3 万人的生活住房需依赖外围地区解决。

(2) 产业准人方面, 深圳市采取高新区领导小组一高新 办一管理服务中心的三级管理模式, 对产业园区实行统一管 理和规划。园区建立之初, 管委会对人园企业的规模和等级 有刚性的标准限定, 要求企业属于特定产业（如电子信息、 集成电路、生物医药)、有独立研发机构、有一定比例的研 发人员和有专利等条件。优先引进技术水平高、效益好、规 模大的企业进人高新区, 并对园区既有低档次产业进行改造, 将难以改造或已划地但没有项目的用地单位强行迁出高新 区, 确保拥有好项目的企业能够进人该区, 加快形成高新区 的支柱产业、骨干产业和名牌产品。

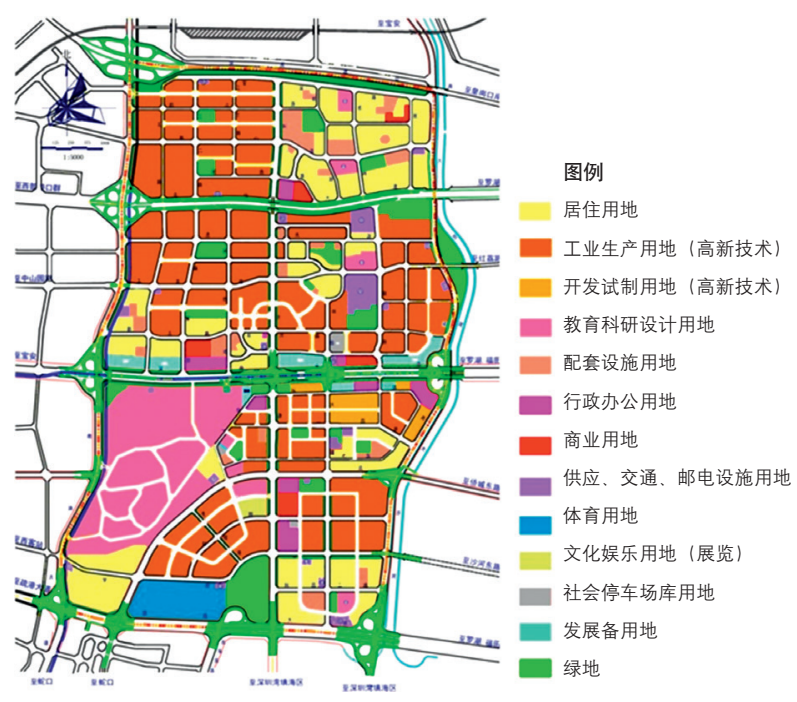

图 3 深圳市高新技术产业园区土地利用规划图 资料来源 : 作者依据 1998 年《深圳市高新技术产业园区土地利用规划》绘制 
（3）政策配给方面，高新区采取封闭式管理模式，率先 在具有明确边界的空间范围内探索企业运行机制和科技体制 改革创新，凡进入产业园区的高新技术企业和项目均可享受 土地使用、海关、住房等方面的优惠政策，其实质是一种相 对刚性的针对物质空间配给政策的方式。

\section{2 产业带（2001一2005 年）: “外向 + 内向” 弹性规 划阶段}

\subsection{1 规划背景}

随着深圳高新技术产业的快速发展, 全市范围内由西向 东规划建设了多个高新技术产业片区，但各个园区内的高新 技术项目用地已趋于饱和, 需求与空间矛盾掣肘高新技术产 业的进一步发展。为控制和预留高新技术产业用地, 突破深 圳市高新技术产业发展空间不足的瓶颈，深圳市开始调整惯 用的刚性产业规划思维，于 2001 年提出构筑高新技术产业 带的战略决定，统筹优化各产业片区的创新资源配置，获取 创新型产业用地的外向弹性。同时编制深圳市高新技术区法 定图则, 以各产业园区为创新单元进行内向挖潜, 为产业发 展提供多样化的空间选择。

\subsection{2 产业带规划中的弹性思维}

一方面, 深圳在市域范围内构建产业带这一空间载体获 取外向弹性。2 001 年 7 月, 中规院编制《深圳市高新技术产 业带规划纲要》, 确定产业带范围并初步布局了以市高新区、 前海片区、大学城片区为核心的创新研发、人才培养、科技 成果孵化基地, 以市大工业区、光明南片区、宝龙一碧岭高 新区、留仙洞片区、观澜一龙华一坂雪岗片区、石岩片区为 支撑的产业化生产、出口加工基地, 以及以葵涌一大鹏片区、 东部海洋产业片区为补充的现代生态农业、海洋生物技术示 范中心。这一时期的产业带规划已具备三规合一的维形, 规 划适度超前, 为产业发展谋划预留了空间。首先, 市高新产 业带管理办公室在产业带上促进高新技术企业落地，一些高 新企业的研发机构设置在产业园区内, 而制造加工部门则 被安排在产业带沿线或产业带上的其他园区, 实现了研发与 制造的空间分化。轨道交通、高速路网和信息网络的横贯联 通进一步增强了产业园区间的功能联系, 加速形成研发一加 工一出口产业链条，使高技术产业在空间拓展上获得了更大 的外向弹性。其次, 政府资源配置和公共服务向产业带倾斜, 产业带可以获得更多的新增用地指标，且国土指标在空间上 的配给不再固化到具体地块, 而是通过总量控制, 由管理办 公室在产业带上灵活调配。此外，物质边界的概念在这一阶 段逐渐弱化，产业优惠政策不再针对空间配给，而是跟着企 业走，依据行业对象分类和项目条件评级进行配给。
另一方面, 深圳在产业园区尺度挖掘空间潜能、寻求内 向弹性。主要体现在片区法定图则对用地性质、开发强度等 指标的弹性控制。在用地性质方面, 允许在具体的规划与 开发建设中依据实际情况灵活合并或细分已划定红线范围 的地块, 并预留发展备用地以应对当前不确定的规划条件 和未来的功能发展变化。不再强制限定地块的某一单一功 能, 而是仅指定地块的主导用地性质和可兼容的其他性质, 提高土地利用的可选择性和复合程度。在开发强度上, 根 据高新技术产业对生产流程、厂房、环境等方面的具体要求, 部分产业园区的法定图则将工业用地容积率这项规定性的 技术经济指标确定为指导性指标, 并尝试以容积率调整通则 的形式控制开发强度, 在不突破单元产业用房总面积上限, 满足贡献率的前提下, 适度提高容积率上线, 拓宽规划指 标的可浮动范围。

\section{3 功能网络 (2006 年至今) : 韧性规划阶段 2.3.1 规划背景}

这一阶段深圳的创新型产业处于成熟稳定期, 在空间上 基本形成了以产业园区为模块单元、以产业带连通融合的点 轴式布局, 但这种简单的复合结构难以支撑创新型产业进一 步提高自主创新能力以及外向拓展的长效需求。而网络结构 是一种能够迅速适应外部环境变化、促进高效创新活动的空 间组织形式, 要素参与的网络越复杂, 网络节点连接数越多, 网络效应更高。因此, 深圳市于 2004 年在国内率先提出建设 “区域创新体系”的构想, 促进企业、政府、大学、科研机 构、中介和服务机构等多主体要素跨越产业带、产业园区的 地理空间边界建立多向的功能联系, 将创新空间拓展至 “虚 拟流” 空间, 形成多中心、多层次、多尺度的创新网络体系。

\subsection{2 功能网络中的韧性思维}

在政策上, 这一时期的创新型产业内涵已经放宽, 不局 限于高新技术产业, 而是将文化创意、新材料等战略性新兴 产业以及金融、商贸会展等高端现代服务业都纳人其中, 以 营造创新生态体系为目标。

对应在空间维上, 规划对创新型产业的空间组织也不 限于高新技术产业园区或高新技术产业带, 而是采取全产业 口径将全市的产业空间要素进行整体安排与重组。在全市层 面，《深圳国家自主创新示范区空间布局规划（2013-2020 年)》几乎将现有的园区都纳人其中, 在市域范围内规划布 局了 “双核驱动、多点支撑” 的多中心大型功能网络, 涵盖 技术创新、高端现代服务业、出口加工区、 $\mathrm{CBD}$ 基地、总 部基地、文化创意、航空城、科技城、低碳城等功能各异、 协同发展的中小型网络。大沙河创新走廊就是其中一个以技 
术创新为发展导向的中型功能网络。通过整合沿线的创新资 源, 构筑由深圳湾高新区、留仙洞、大学城产业片区为核心 的新兴产业发展主轴, 并向两侧片区辐射, 形成文化创意产 业带和生态科技产业带 (图 5), 呈现出典型的网络化空间 结构。在更小的园区尺度, 人口、产业、基础设施布局也更 加体现出产城互促、产城融合的规划理念。通过营造绿色开 敞空间和景观节点轴线, 配建体育馆、购物中心、酒吧、画 廊等公共配套设施, 促进生产、研发、居住、商业片区间的 互动与融合。同时园区与园区之间、园区与外部区域之间也 实现了更开放的网络联系。

在时间维上, 制定区域创新体系的近远期建设方案, 采 取整体规划、分片实施、分步启动、滚动开发的精细化管理 方式, 使规划行动能根据外部环境变化及时得到调整, 满足 功能网络无限衍生、不断发展的动态长效需求。例如, 大沙 河创新走廊规划序列化地分解了建设行动：近期 “全面布 点”, 新增 10 个产业园区和配套住房以培育新的增长极; 中 期 “聚点成片”, 推进国际知识创新村、大沙河生态文化长 廊等小型网络建设, 并以旧工业区升级改造为手段置换创新 空间；远期 “连片成带”，促进流域沿线 6 大发展片区高端 创新资源的整合与互动, 集聚创新龙头企业和高层次人才, 发挥自主创新示范的核心引领作用。

\section{3 深圳市创新型产业韧性规划思考}

深圳市创新型产业经历了 “产业园区一产业带一功能网 络” 的空间形态演化, 其后蕴含的规划思维与技术也发生着 从刚性规划到弹性规划再到韧性规划的转变。通过厘清创新 型产业韧性规划中空间拓展需求、点轴式空间骨架、空间组 织模块等刚性表现形式与土地复合利用、区间式指标控制、
低效空间置换等弹性技术工具, 构建由结构韧性、控制韧性 与过程韧性构成的韧性规划控制体系。

\section{1 结构㓞性一以刚性要素构建稳定、开放的空间骨架}

以创新型产业持续性的空间拓展需求、点轴式空间骨架、 模块化的空间组织形式等刚性要素作为空间规划的基本零 件, 应用弹性化手段进行有机组织与整合, 形成稳定而开放 的多中心网络化空间结构。

\subsection{1 获取产业发展的有效空间}

创新型产业的快速发展需要充足的空间作为支撑。深圳 独特的地缘优势、活跃的市场化环境以及有序的政府引导, 为高新技术产业的超高速发展提供了沃土, 但由于深圳地域 空间的有限性, 规划建设的产业园区内高新技术用地很快趋 于饱和。为了突破空间资源的瓶颈, 深圳市在不同阶段调整 规划布局, 采用各种空间利用形式应对创新型产业持续性的 空间拓展需求。从早期产业园在全市范围内的复制与扩散, 到以产业带为载体连通整合沿线资源、运用弹性工具内向挖 掘存量空间, 再到布局尺度不一、类型丰富的多中心功能网 络, 创新型产业的空间供给逐渐由物质空间向功能空间延伸。

\subsection{2 布局点轴式空间骨架}

深圳创新型产业的空间布局演化路径遵循点一轴开发模 式, 创新活动最先集中在具有良好条件的产业园区内, 形成 创新增长极, 随着产业园区的增多和壮大, 增长极间相互联 结形成发展轴, 即高新技术产业带, 这种点轴布局形态在全 市尺度上构成了创新产业规划的基本骨架，后期出现的各类 功能网络概念、后续修编的创新产业规划均是在这一基本框

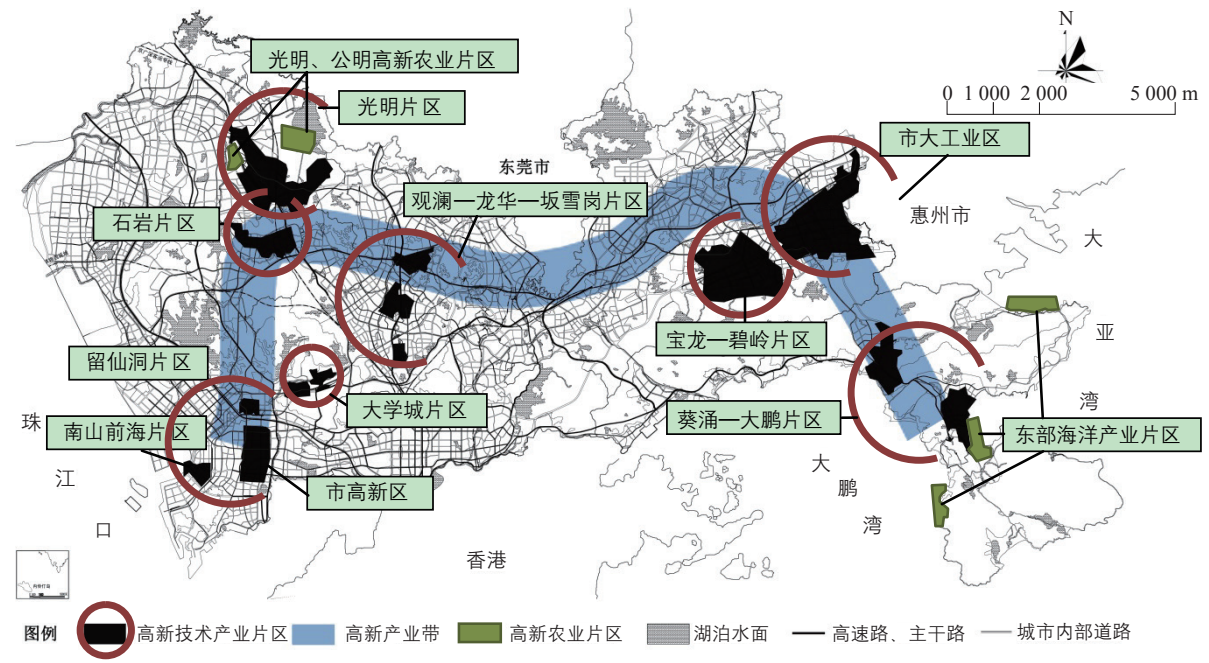

图 4 深圳市高新技术产业带空间布局

资料来源 : 作者依据《深圳市高新技术产业带十一五发展规划》绘制

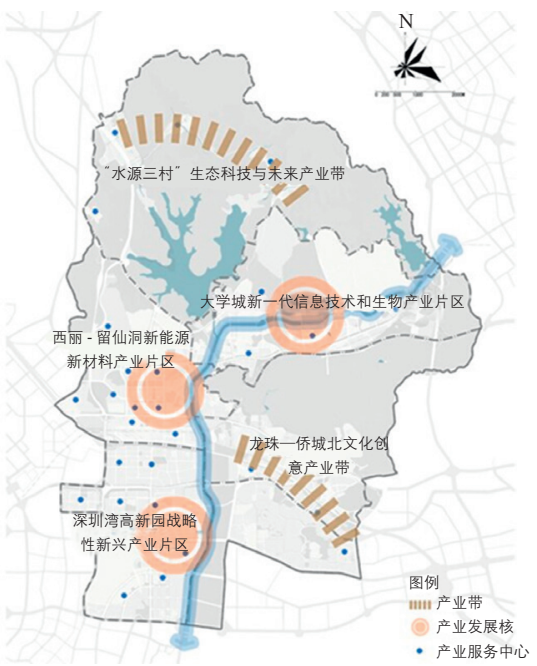

图 5 大沙河创新走廊产业空间布局 资料来源: 大沙河创新走廊官方网站一规划布局一产 业布局 http://dshcxzl.szns.gov.cn/summary-Industry.aspx 
架下, 基于区域产业现状、土地开发潜力、交通基础设施及 市场需求, 对片区产业布局形态和微环境的塑造、调整与提 升。这种外向延展、内向关联的开放式空间骨架能够高效集 聚全市核心创新资源, 为基本的产业创新活动提供强大支撑。

\subsection{3 采用模块化的组织形式}

深圳市创新型产业规划采用不同尺度的“功能网络”作 为空间组织模块应对外部环境的剧烈变化。产业园区是模块 中的最小创新单元, 产业带将各个单元串联为带状区域, 功 能网络则通过促进多个园区、多条产业带的功能联系组建成 为创新体系的基本模块。在全市尺度上, 形成了深圳国家自 主创新示范区大型功能网络; 在片区尺度上, 形成了大沙河 创新走廊等中型功能网络; 在片区内部, 又形成了宝安桃花 源科技园、华为科技城、国际知识创新村等具有丰富内涵的 小型功能网络。这种多层次、模块化、组团式的空间安排进 一步提升了原有点轴式骨架的稳定性。

\section{2 控制韧性一以弹性工具优化规划控制指标的空间 配置}

运用土地利用相容性、容积率奖励、开发权转移等弹性 工具为用地性质、开发强度等规划控制指标设定可浮动区间， 促进规划指标在空间上的优化配置，增加政府对各类空间资 源的整体统筹。

\subsection{1 可复合的用地性质}

深圳市在推进产业外向拓展的同时尝试内向挖潜。产业 规划也逐渐改变传统对用地性质这一控制性指标的单一性规 定, 为各个地块提供可选择的用地类型范围或反向规定所限 制使用的类型, 以增加土地利用的兼容性, 更好地适应创新 产业对空间日益多样化灵活化的选择需求。除了鼓励土地复 合利用, 2013 年《深圳市规划标准与准则》还通过调整用 地分类、新增 $\mathrm{M} 0$ 新型产业用地的方式适应产业转型升级的 趋势与特点。 $\mathrm{M} 0$ 用地允许制造业与商务、办公和公寓进行 一定比例的混合, 融合研发、创意、设计、中试、无污染生 产等创新型产业功能以及相关配套服务活动, 同时给予使用 者容积率、地价方面的优惠政策, 为企业的转型升级提供低 成本的空间支持, 也为战略新兴产业、“2.5 产业”、商贸物 流业提供良好的生长环境。

\subsection{2 可浮动的开发强度}

容积率是与市场经济活动关联度最高的规划指标之一, 因此在刚性约束条件下, 应适度增加容积率指标的弹性浮动 范围以应对灵活多变的市场需求。在深圳创新型产业规划实
践中, 部分园区的法定图则已将容积率这一规定性指标调整 为指导性指标, 改变了传统规划对整个规划区内的建筑总面 积、容积率等指标设定唯一值的方法, 尝试采用设定上下 阈值的方式为某一类用地的开发强度赋予弹性区间, 在满足 工程地质安全建设相关规定的前提下根据实际情况进行建 设。如南山 07 号片区 (高新技术区) 首次采用通则式容积 率确定机制, 规定在满足用房、用地贡献率, 不突破单元产 业用房总面积阈值的情形下, 适当提高产业片区、轨道站点 $200 \mathrm{~m}$ 范围内及主要道路沿线 M0 用地的容积率上限, 提升 规划对新增产业门类的兼容性。

\subsection{3 可置换的低效空间}

为缓解创新产业发展过程中物质空间和功能需求的矛 盾, 深圳采用 “空间置换” 的规划工具对旧工业区进行升级 改造, 对质量较差、档次较低的厂房进行拆除重建, 引导符 合产业导向的高新技术、高附加值、低能耗企业向园区集聚。 但是早期的深圳旧工业区土地产权多样, 基于个体需求的改 造支离破碎。对此, 深圳市引人 “城市更新单元” 对零散土 地进行整合, 突破行政单位或用地权属所限, 将工业区用地 划分为成熟型、重点型和一般型更新单元, 在整体统筹的基 础上, 分单元实施更新策略, 促进置换空间的完整性。除此 之外, 深圳还引人容积率奖励、开发权转移等市场机制, 对 用于道路、城市基础设施、公共绿地、政府创新型产业用房 建设的地块给予一定的容积率奖励, 或将既有用地的开发权 转移至别的区域, 在原有地块上挪腾空间指标用于公共事务 建设, 并相应提高新的开发地块的容积率上限, 以鼓励开发 商维护公共利益的建设行为。

\section{3 过程韧性一以刚性机制推进渐进式、协商式产业 规划}

近年来, 深圳应用刚性制度化管理手段建立了多层次、 多元参与的规划编制与实施机制, 使创新型产业规划逐渐由 传统的蓝图式远景规划向渐进式、协商式规划转变, 实现其 与同时期城市总体规划在产业发展目标和产业用地空间布局 上的充分衔接与深度融合。

在微观园区层面, 强化市高新区领导小组对高新区规划 建设管理的决策作用, 明确区政府、新区管委会对各片区新 型高科技园建设的管理职责, 建立年度、季度工作会议制度, 定期研究解决高新区发展中的重大问题, 依据产业发展形势 及时调整近远期战略计划。同时, 成立深圳高新区发展专家 咨询委员会, 建立起由专家学者、企业负责人、国内外研究 机构以及社会公众多元参与的决策咨询与沟通协商机制。

在宏观层面, 由科技部牵头组织成立深圳建设国家自主 
创新示范区部际协调小组, 协调发改委、财政部、国土资源部、 住建部等单位在职责范围内共同支持示范区建设, 并联合审 议通过《深圳国家自主创新示范区空间布局规划（2015一 2020)》, 提出优先打造知识技术创新和高端现代服务业创新 驱动核, 引领国家产业化基地、出口加工区等多点支撑的新 型产业园建设, 再依托区域发展协调互动, 规划布局国际低 碳城、华为科技城等特色产业功能组团, 渐进式、有序化地 推进产业空间布局的优化调整。

\section{4 结论}

在城市化、全球化背景下, 中国的规划技术正由刚性 走向弹性, 面向创新的产业空间布局规划也面临转型。本文 以首个国家创新型城市试点一一深圳为例, 通过探讨其创 新型产业布局形式的演变与空间规划特征得到以下结论 :

（1）深圳的创新型产业空间规划经历了 “刚性一弹性一韧 性” 的转变, 逐渐改变传统规划对物质空间的刚性管控, 转 而关注功能空间的联系与互动, 衍生出产业园区、产业带、 功能网络等具有丰富内涵的空间形态以应对复杂多变的社 会经济环境。(2) 寻求刚性与弹性的有机耦合、建构韧性 规划控制体系是推进创新型产业可持续发展的必然趋势。在 空间结构方面, 通过点轴式的基本骨架及模块化的组织方 式塑造开放、稳定的多中心网络化结构; 在规划控制方面, 采取弹性手段为规划控制指标设定浮动区间, 促进规划指 标的优化配置。在规划过程方面, 建立刚性管理机制保障 渐进式、协商式的规划组织方式, 赋予规划实践对外在环 境变化的适应力。UPI

\section{参考文献}

[1] 郡亦文, 徐江. 城市韧性: 基于国际文献综述的概念解析 [J]. 国际城市 规划, 2015, 30(2): 48-54.

[2] 郭荣朝, 苗长虹. 基于特色产业簇群的城市群空间结构优化研究 [J]. 人 文地理, 2010, 25(5): 47-52.

[3] 晓亚, 顾启源. 评介《城市: 它的发展、衰败与未来》[J]. 城市规划, 1986(3):64.

[4] 刘壁, 全德, 金珊, 等. 韧性规划・ 区间控制 - 动态组织——深圳市弹 性规划经验总结与方法提炼 [J]. 规划师, 2012, 28(5): 36-41.

[5]赵珂, 赵钢。“非确定性”城市规划思想 []. 城市规划汇刊, 2004(2): 33-36.

[6] Wallace Mike. Flexible Planning: A Key to the Management of Multiple Innovations[J]. Educational Management Administration \& Leadership, 1991, 12(3): 180-192.

[7] 刘㔟, 李贵才, 尹小玲, 等. 走向多维弹性: 深圳市弹性规划演进脉络 研究 [J]. 城市规划学刊, 2012(1):63-70.

[8] 张友安, 郑伟元. 土地利用总体规划的刚性与弹性 [J]. 中国土地科学, 2004, 18(1): 24-27.

[9] 尹奇, 吴次芳, 罗罡辉. 土地利用的弹性规划研究 [J]. 农业工程学报, 2006, 22(1): 65-68.

[10] 张鸿. 刚性规划下的弹性利用 [J]. 中国土地, 2009(9):55.

[11] 仇保兴。市场失效、市场界限与城市规划调控 [J]. 城市发展研究, 2004, 11(5): 1-7.
[12] 刘篠, 王铮, 赵晶媛. 政府在高技术产业集群中的作用一以深圳为 例 [J]. 科研管理 , 2006, 27(4): 36-43.

[13] 覃成林。高新技术产业布局特征分析 [J]. 人文地理, 2003, 18(5): 38-41.

[14] 陈伟新, 吴晓莉. 高新技术产业的空间选择与规划——深圳为例 [J]. 城市规划, 2002, 26(4): 80-83.

[15] 魏心镇, 王缉慈、新的产业空间: 高技术产业开发区的发展与布局 [M] 北京: 北京大学出版社, 1993: 108-120.

[16] 张孝开, 刘雪霞. 科技园区规划布局模式探讨一以富士康南宁科技 园区规划为例 [J]. 规划师, 2013, 29(1): 85-88.

[17] 王铮, 赵晶媛, 刘符, 等。高技术产业空间格局演变规律及相关因素分 析 [J]. 科学学研究, 2006, 24(2): 227-232.

[18] 陈汉欣。深圳高新技术产业的发展与布局 [J]. 经济地理, 2002, 22(3) 269-273.

[19] 刘符, 王铮, 赵晶媛. 政府在高技术产业集群中的作用一以深圳为 例 [J]. 科研管理, 2006(4): 36-43.

[20] 夏海钧. 中国高新技术产业开发区发展研究 [D].广州: 暨南大学, 2001

[21] 张晓平, 陆大道. 中国西部地区高新技术产业发展战略及空间组织形 式 [J]. 地理科学, 2004, 24(2): 129-135.

[22] 王富海. 从规划体系到规划制度——深圳城市规划历程剖析 [J]. 城市 规划, 2000, 24(1): 28-33.

[23] 刘㕵.社会主义市场经济背景下韧性规划思想的显现与理论建构一 基于深圳市城市规划实践 (1979-2011)[J]. 城市规划，2014, 38(11): 59-64.

[24] 元世勇, 刘海润。现代汉语新词语词典 [M]. 上海: 上海辞书出版社, 2009: 155

[25] 新华社.中共中央国务院关于进一步加强城市规划建设管理工 作的若干意见 [EB/OL]. [2016-02-23]. http://www.hinews.cn/news/ system/2016/02/23/030155901.shtml

[26] 汪余. 浅谈控制性详细规划的刚性与弹性 [J]. 科学之友, 2011, 13: 155-156.

[27] 胡健, 王雷. 土地利用规划的刚性与弹性控制途径探讨 [J]. 规划师, 2009, 25(10): 85-89.

[28] 贺传皎, 王旭, 邹兵. 由 “产城互促” 到“产城融合”一深圳市产 业布局规划的思路与方法 [J]. 城市规划学刊, 2012(5): 30-36.

[29] 吴扬, 王振波, 徐建刚. 我国产业规划的研究进展与展望 [J]. 现代城市 研究, 2008, 23(1): 6-13.

[30] 阎金铎. 中国中学教学百科学术——物理卷 [M]. 沈阳出版社, 1990: 3 .

[31] 黄晓军, 黄馨。弹性城市及其规划框架初探 [J]. 城市规划, 2015, 39(2): 50-56.

[32] 李粀玥, 牛品一, 顾朝林. 弹性城市研究框架综述 [J]. 城市规划学刊, 2014(5): 23-31.

[33] R.A. Resilience Alliance: Key Concepts[EB/OL]. 2002. http://www. resalliance.org/index.php/key concepts.

[34] 郝凌佳, 钟悠, 王承慧。弹性规划理念下的文化创意产业集聚区规划 探讨一以中国宋庄文化创意产业集聚区为例 [J]. 规划师, 2015, 31(7): 73-79.

[35] 蔡建明, 郭华, 汪德根, 国外弹性城市研究述评 [J]. 地理科学进展, 2012, 31(10): 1245-1255.

[36] 王卓, 尚涛, 柳桃青. 基于非确定性思考下的城市规划新思维探讨 [J]. 武汉大学学报 (工学版), 2007, 40(5): 103-107.

[37] 王震, 杨忠伟, 张承。一种协调开发区近远期产业布局的弹性控制方 法——“灰色用地”规划方法 [J]. 国际城市规划, 2014, 29(2): 105-110.

[38] 舒倩, 王戟, 谢映。产城融合视角下产业园建设用地弹性规划的思 考——长沙高新区为例 $[C] / /$ 中国城市规划学会. 城乡治理与规划 改革一2014 中国城市规划年会论文集 (09 城市总体规划). 中国城市 规划学会, 2014: 9 .

[39] 丁灵鸽, 陈天, 李磊. 弹性理念主导下的产业园区规划实践探索— 以天津中华自行车王国产业园区为例 [J]. 城市规划, 2010, 34(9): 93-96.

[40] 徐江, 郡亦文. 韧性城市: 应对城市危机的新思路 [J]. 国际城市规划, 2015, 30(2): 1-3.

(本文编辑：许玫) 